\title{
Assessment of Structural and Conservation Practices on Vernacular Houses of Axum, Ethiopia
}

\author{
Gebremeskel Teweldemedhn Desta
}

School of Architecture \& Urban Planning, Ethiopian Institute of Technology, Mekelle University, Mekelle, Ethiopia

\section{Email address:}

gebremeskel27arch@gmail.com, gebremeskel.teweldemedhn@mu.edu.et

\section{To cite this article:}

Gebremeskel Teweldemedhn Desta. Assessment of Structural and Conservation Practices on Vernacular Houses of Axum, Ethiopia. International Journal of Architecture, Arts and Applications. Vol. 5, No. 1, 2019, pp. 18-28. doi: 10.11648/j.ijaaa.20190501.13

Received: February 14, 2019; Accepted: March 19, 2019; Published: May 11, 2019

\begin{abstract}
Historical buildings are one of the physical testimonies of early settlements and civilizations. The creativity of space, form and order of their houses, the techniques and technologies they have used, the methodologies of construction and building material selection is a mirror of the society's knowledge and wisdom. But, those traditional houses that are heritages of Aksum are not documented yet. In order to document those traditional historical houses, identifying whether it is on its original fabric or transformed is a critical lesson. Therefore the main aim of this study is to investigate the physical condition of the selected vernacular houses and to assess their conservation practices. Using field visit, observations, structured and nonstructured questionnaires and interviews, cross checking different data sources are used for qualitative data collections and the data has analyzed. From the selected case studies, most of them their physical structure is not at a good condition because of ownership issues and improper conservation practices due to need of modernization and urbanization like cement plastering, chemical paint, electricity installation and others that affect its original fabric. Responsible parties like governmental offices, universities, professional experts and stakeholders should document the vernacular houses and the conservation practices at different time and they should prepare conservation management plan or guidelines for the specific site to manage the conservation activities and practices. The responsible parties should work with the community in awareness creation to preserve those vernacular houses.
\end{abstract}

Keywords: Vernacular Houses, Heritage, Structural Assessment, Conservation Practice Assessment, Aksum, Ethiopia

\section{Introduction}

The vernacular attempts to define a common architecture of a people;

Vernacular houses or traditional houses are buildings which have not been professionally designed. They are "buildings of the people", by the people but not for the people "accommodating the values, economies and ways of life of the cultures that produce them" [1]

It can be said that the traditional is what is embodied in the transmission process while vernacular is the language used in the development of the traditions. "The terms traditional and vernacular meet where vernacular goes back to its Latin meaning as "things that are homemade, homespun, homegrown, not destined for the marketplace, but are for home use only" [2].

Vernacular architecture defines as: Comprising the dwellings and all other buildings of the people. Related to their environmental contexts and available resources they are customarily owner-or community-built, utilizing traditional technologies. All forms of vernacular architecture are built to meet specific needs, accommodating the values, economies and ways of life of the cultures that produce them [3].

Most of the vernacular houses are qualified as vernacular because of the construction materials, space and form. Materials, construction, and technology are best treated as modifying factors, rather than form determinants, because they decide neither what is to be built nor its form this is decided on other grounds [4].

Historic buildings are broad and flexible concepts that refer to valuable buildings and constructions left by history and able to witness some development though civilization, meaningful development or certain historical events, urban or rural environment and certain historical events. Historic buildings are usually characterized by a particular microclimate due to their high thermal inertia that may require the use of 
mechanical systems to control the environment [5].

The value of historic building includes cultural value and economic value. Economic value means land value and value of the building itself; cultural value includes historical, architectural, cultural, artistic and social value [6].

All building materials decay eventually due to sunlight, rain and wind, and therefore they require continued attention if a building's condition is to be maintained. Modest spending on regular maintenance can reduce the need for costly repairs, protect the fabric of your building and save you money in the longer term. Conservation of Heritage buildings can be defined as Routine, cyclical, non-destructive actions necessary to slow the deterioration of a historic place. It entails periodic inspection; routine, cyclical, nondestructive cleaning; minor repair and refinishing operations; replacement of damaged or deteriorated materials that are impractical to save [7].

In heritage buildings, historical features are tangible aspects of cultural heritage that provide an identity we affiliate with [8]. It reminds us that heritage buildings go beyond aesthetic appreciation and provide a 'sense of place' [9]. Conservation by definition means the retention of existing buildings without altering or destroying character or detail, even though repairs or changes may be necessary [10]. Conservation of historic buildings is sensitive to the preservation of as much original fabric as possible, and to distinguish new additions and changes from the originally existing structure. Conservation allows considerable intervention on condition that changes done are of architectural and historic interest that enhance and respect the existing building character. It is a process that leads to prolonging the life of the building and its utilization. While its importance is clear, heritage building conservation is a complicated task that follows some strict guidelines and procedures.

In order to document heritage buildings or traditional historical houses, identifying whether it is on its original fabric or transformed is a critical lesson.

Traditional houses that are heritages of Aksum are not documented yet. In order to document those traditional historical houses, identifying whether it is on its original fabric or transformed is a critical lesson. Therefore the main aim of this study is to investigate the physical condition of the selected vernacular houses and to assess their conservation practices. Using field visit, observations, structured and non-structured questionnaires and interviews, using photographs, Drawings, cross checking different data sources are used for qualitative data collections.

\section{Vernacular Architecture of Axum}

\subsection{Location}

Axum is a city in the northern part of Ethiopia, Tigrai regional state in central zone of Tigrai. And it is located 1,020. K.M from Addis Ababa, the capital city of Ethiopia or 240 K.M from Mekelle the capital city of Tigrai regional state and its location is $14^{\circ} 7{ }^{\prime} 25.01^{\prime \prime} \mathrm{N}$ and $38^{\circ} 43^{\prime} 32.75^{\prime \prime} \mathrm{E}$ at $2100 \mathrm{~m}$ above sea level. Its average temperature varies from 23 to $30^{\circ} \mathrm{C}$ in different seasons [11].

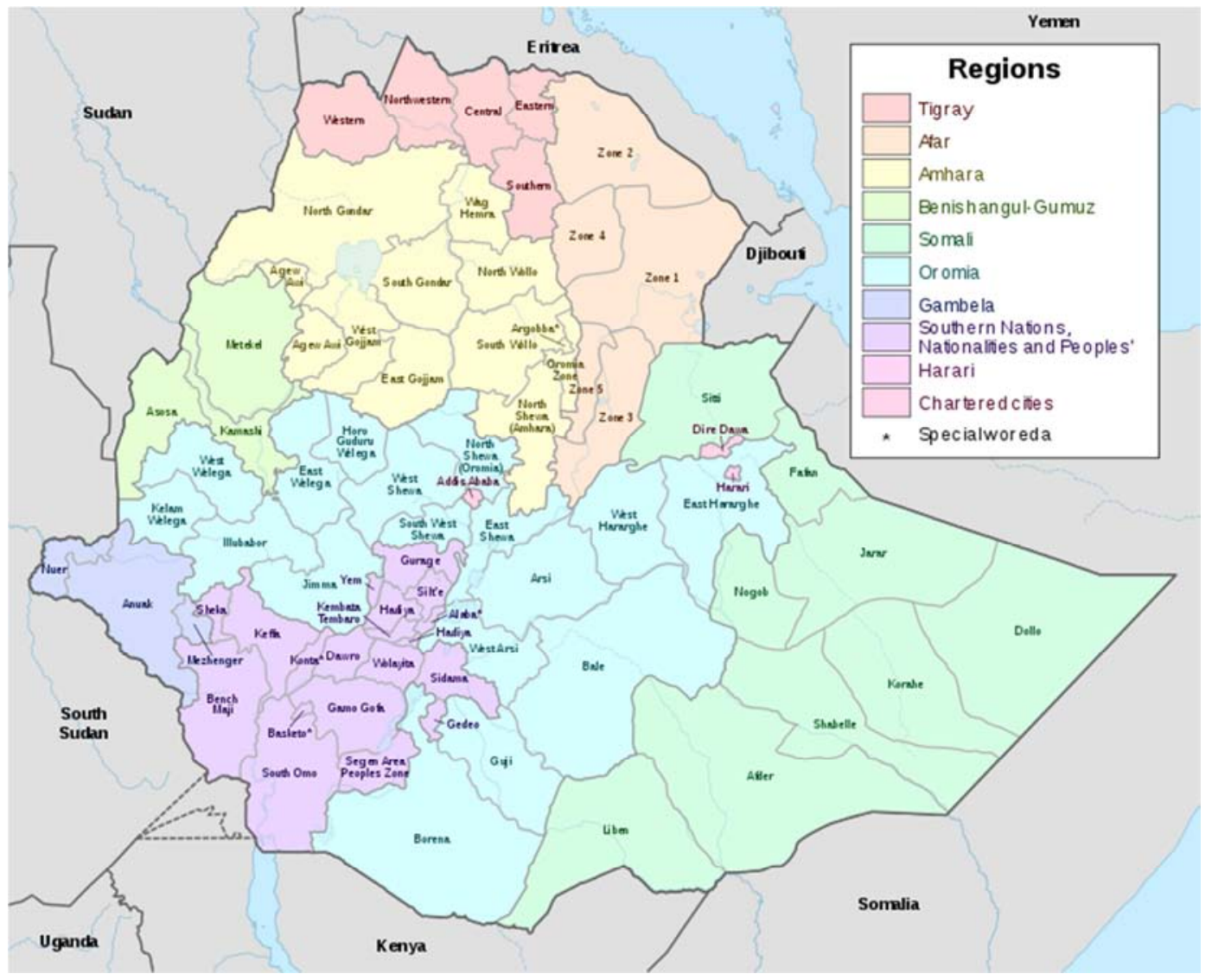




\section{AKSUM WORLD HERITAGE SITE}

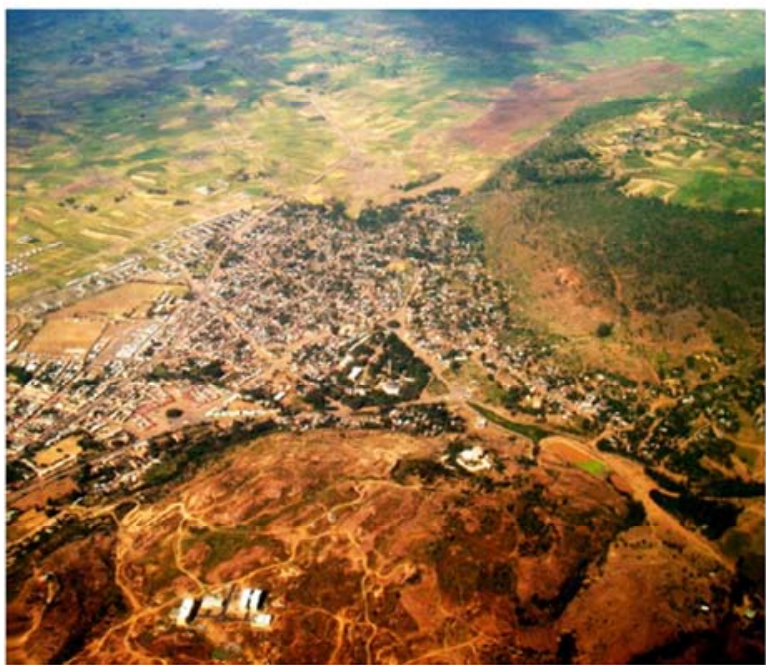

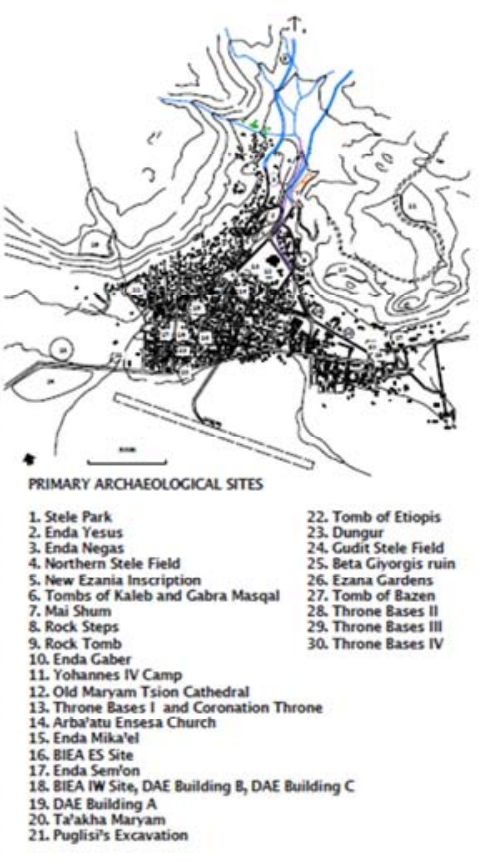

Figure 1. Map of Tigrai, Ethiopia and topographic map of Axum and its archeological sites (TNRS).

\subsection{History}

Axum city is the capital of the Kingdom of Axum. It is one of the oldest continuously inhabited places in Africa. Axum was a naval and trading power that ruled the region from about $400 \mathrm{BC}$ into the 10th century. In 1980, UNESCO added Axum's archaeological sites to its list of World Heritage Sites due to their historic value [12].

Specifically Axum town is highly endowed with various tourist attractions such as the monolithic obelisks, St. Marry of Zion church compound is believed to contain the original Arc of the convent, the open-air Museums, king Ezana Park, king Bazen, Kaleb and Gebremeskels tombs, different churches and ruins etc. [12]

Aksum qualifies for two of the criteria of the UNESCO Convention in accordance with the call of the World Heritage Committee [13]. The two criteria that have been accepted so far for qualifying Aksum to the World Heritage are (I) a representation of "a masterpiece of human creative genius" [13].
Referring to the sophisticated decorated and non-decorated monolithic stele of Aksum, The stele's weights are recorded up to about 520 tons and their heights up to $33 \mathrm{~m}$. They were quarried, carved and transported from the granite hills located 5 $\mathrm{km}$ away from the town of Aksum. The second one refers to criterion as representing "an outstanding example of a type of building, architectural or technological ensemble or landscape which illustrates (a) significant stage(s) in human history" [14].

Referring to the landscape of the town of Aksum and its surroundings by preserving the architectures of the Aksumites together with the archaeological ruins [15].

The remnants are found in the old Aksum town and in its outskirts. The remnants include the sixth century AD Tombs of Kaléb and Gebre Mesqel located about 2 kilometers to its north. The relics demonstrate that the same civilization represents a significant stage in human history as Aksum has been recognized as one of the four great civilizations in the World between the 3rd and 4th centuries AD [16].

\subsection{Heritage Buildings and Heritage Sites of Axum}

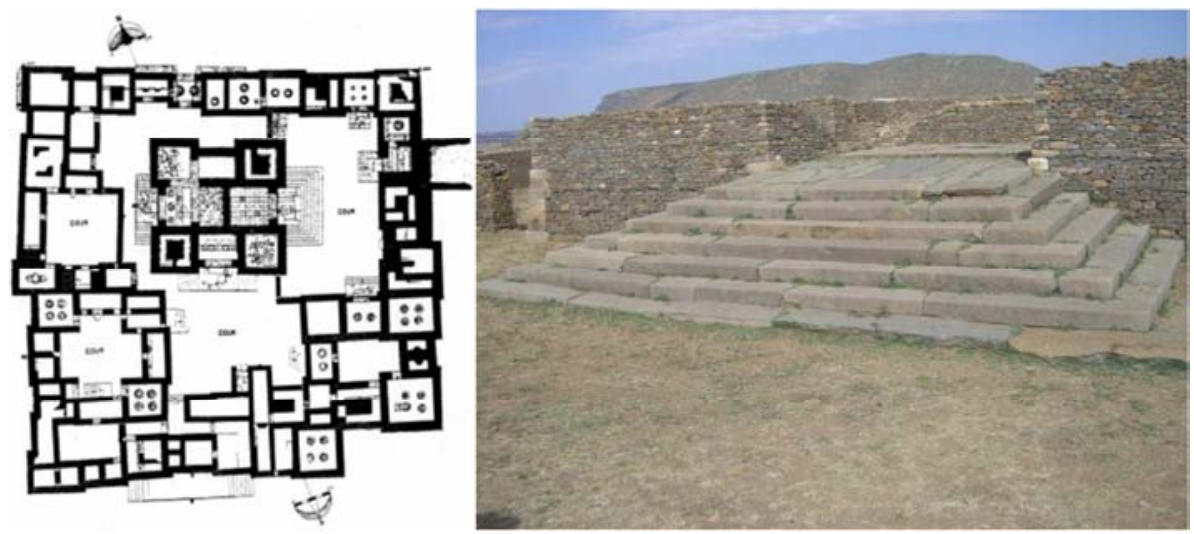

Figure 2. Palace of Dingur dating to 1000 B.C [16]. 


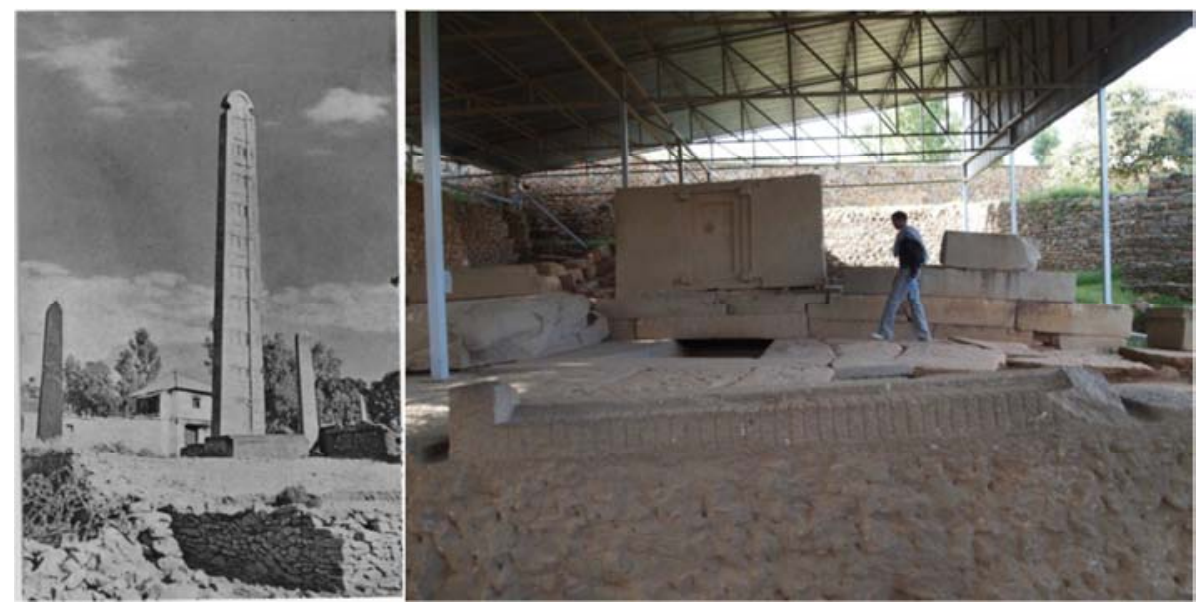

Figure 3. Axum Stale site, false door of King Romhay temple and Axumite measurements dating to $4^{\text {th }}$ century B.C to $4^{\text {th }}$ century A.D [13].
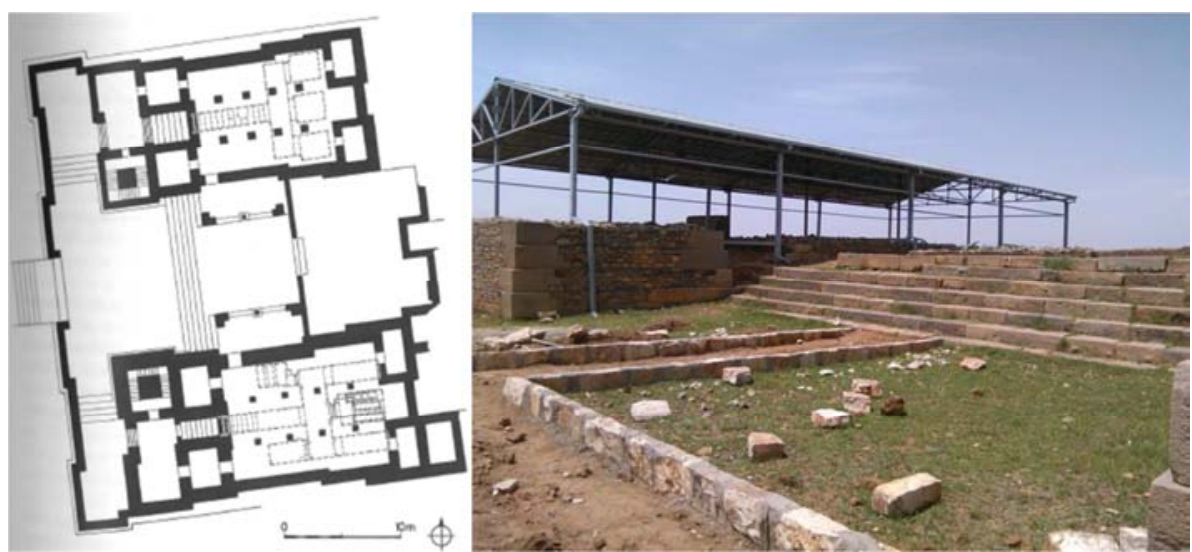

Figure 4. Tomb of Emperor Kaleb and Gebremeskel dating to $6^{\text {th }}$ century AD [16].

3. Case Studies on Assessment of Structural and Conservation Practices of Some Heritage Buildings in Axum

\subsection{Case Study 1, Ayne Mahber / Haleka Teweldebirhan Gebremedhin Building}

This historic building is two story or "Debri" rectangular building, located in Axum historic town which is northern parts of Tigrai region and its absolute locations of this building is $14^{\circ} 21^{\prime} 33^{\prime \prime} \mathrm{N}$ and $38^{\circ} 42^{\prime} 32.53^{\prime \prime E}$. It also relatively located on "Geleemni"/Kebele 03 and house no of 39 to the north of Axum monuments approximately $400 \mathrm{~m}$ far from Axum tsion mariyam church to the north direction.

The daughter of Tewldebirhan, Sarah Teweldebirhan, lives in the building at this time. According to Sarah the building aged to 110 years.
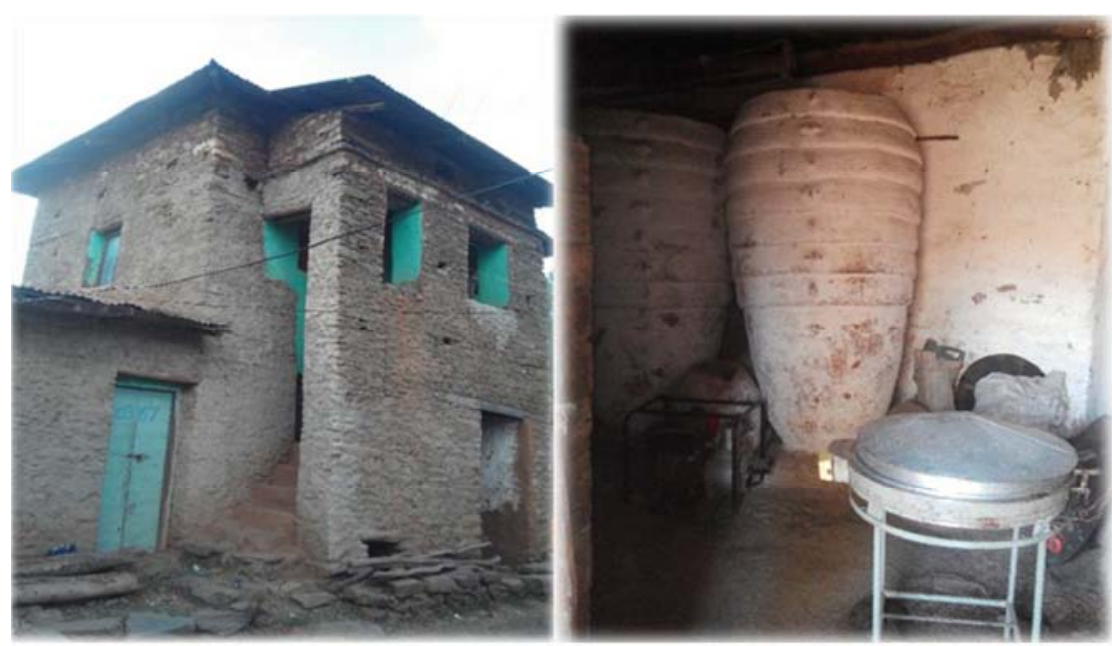

Figure 5. The building and grain storage "Kefo" in ground floor (by the author). 

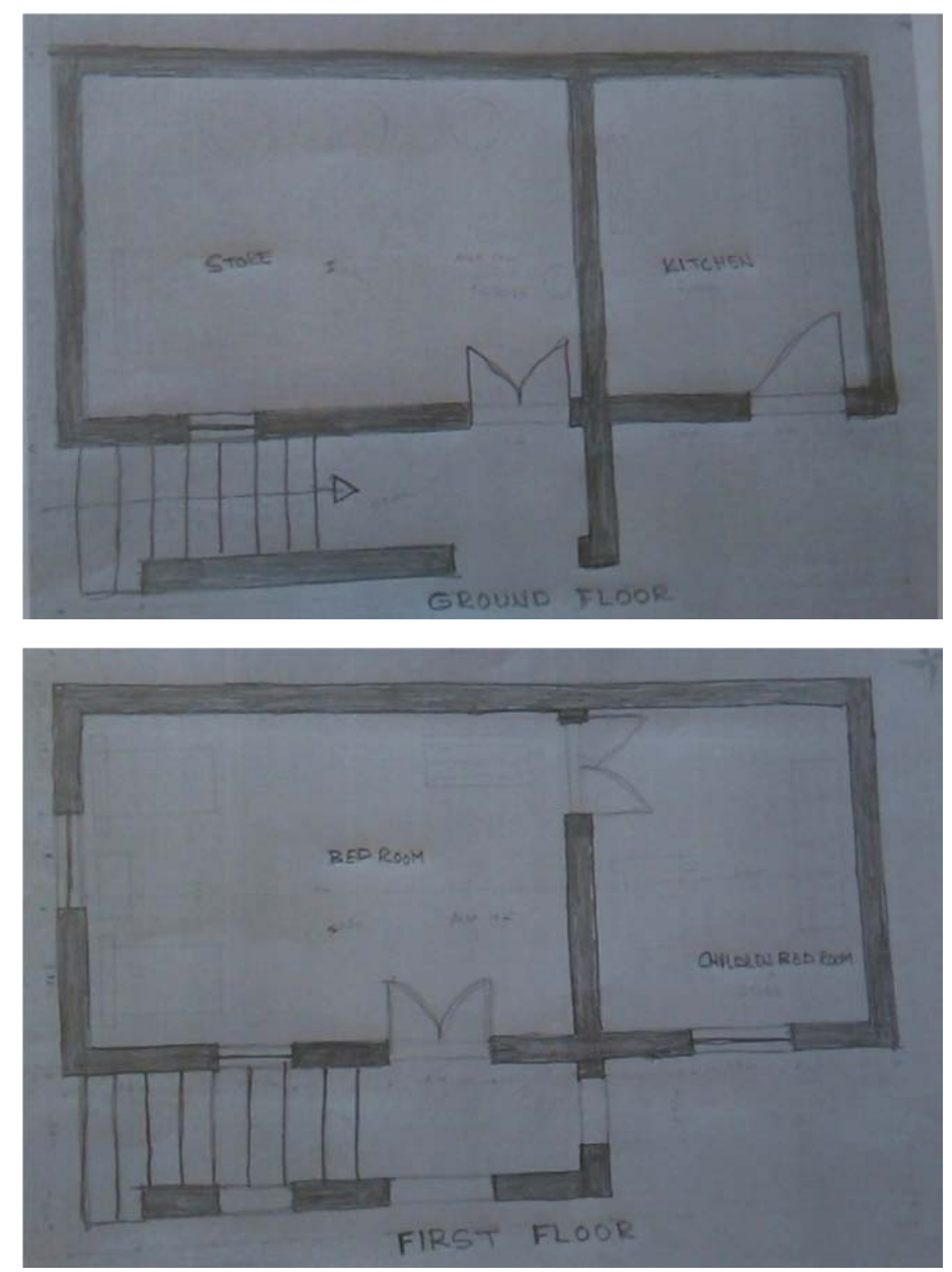

Figure 6. Ground and First floor plan respectively (by the author).

\subsubsection{Structural Assessment of the Building}

The building wall is constructed by stone and mud with 50 $\mathrm{cm}$ thick and $6.5 \mathrm{~m}$ high. Its floor is constructed by wooden materials and mud (earthen floor) which is $30 \mathrm{~cm}$ thick.

The ceiling is bamboo and wooden materials. The wall internal structure is plastered by mud and local lime mixes.
The wooden materials of the floor and ceiling are deteriorated. Its wall and plastering's has cracks especially in ground floor as in the picture below shown.

It has wooden door and window. Horns of goat inserts in the wall for coat and goods hanging.
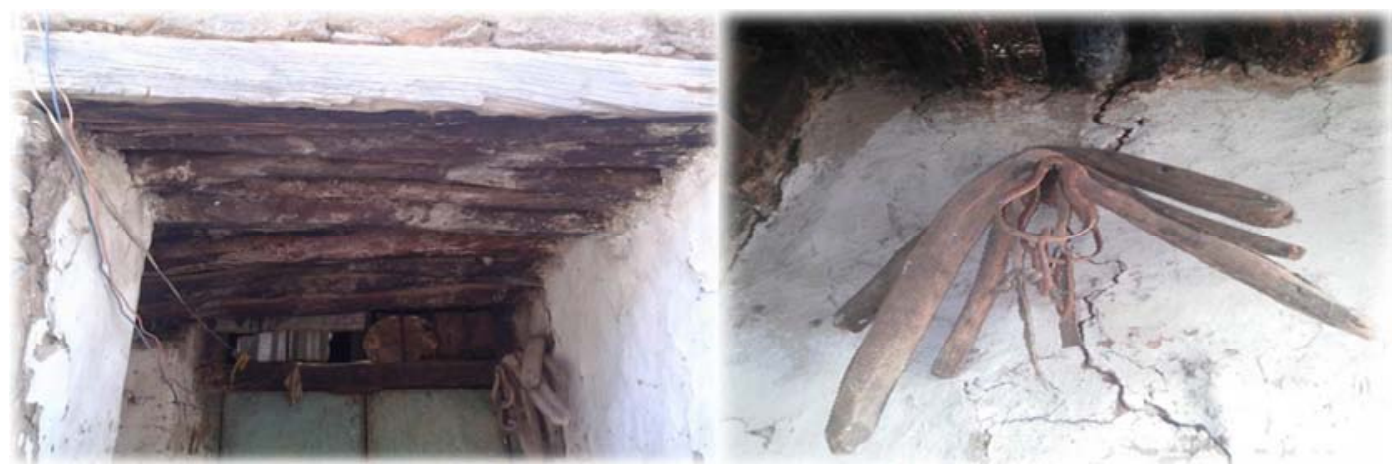

Figure 7. Deteriorated floor and cracked wall (by the author). 


\subsubsection{Assessment of Conservation Practices of the Building}

Before 30 years they have try to paint the balcony or lobby by chemical paints because of the urbanization and introduction of new paint production to area.

In 1992 G.C the external wall has plastered partially by cement material to protect from external wall cracking and to protect from erosion of mud, which is adhesive material of the stone masonry.

\subsection{Case Study 2, Kegnazmach Abreha Meshesha Building}

This historic building is two story or "Debri" circular building, located in Axum historic town which is northern parts of Tigrai region and its absolute locations of this building is $14^{\circ} 23^{\prime} 35^{\prime \prime} \mathrm{N}$ and $38^{\circ} 45^{\prime} 8.58 .7^{\prime \prime E}$. It also relatively located on "Geleemni"/Kebele 03 and house no of 95 to the north east of Axum monuments approximately $350 \mathrm{~m}$ far from Axum tsion mariyam church to the north east direction.

Currently, Selamawit Solomon Abreha, a grandchild of Kegnazmach Abreha Meshesha, is living in the building. According to Selamawit the building is aged to 123 years.

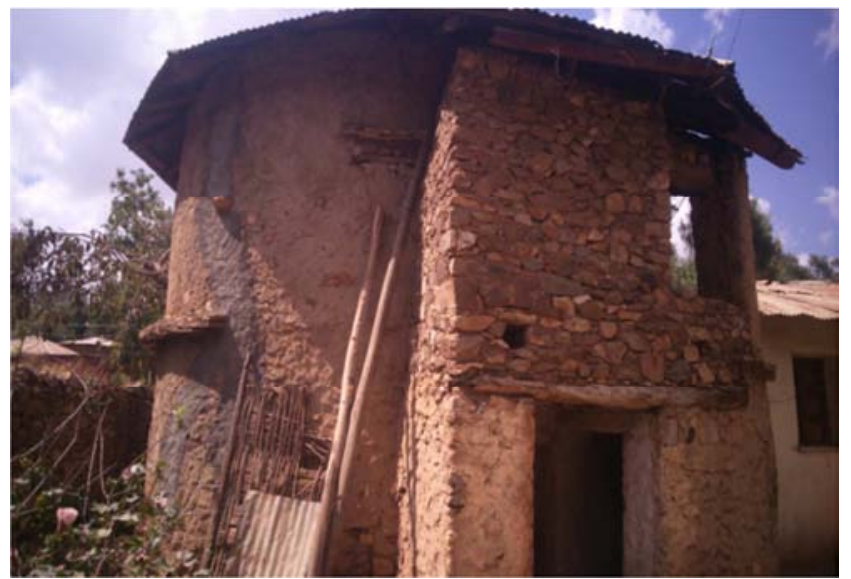

Figure 8. Kegnazmach Abreha Meshesha building (by the author).

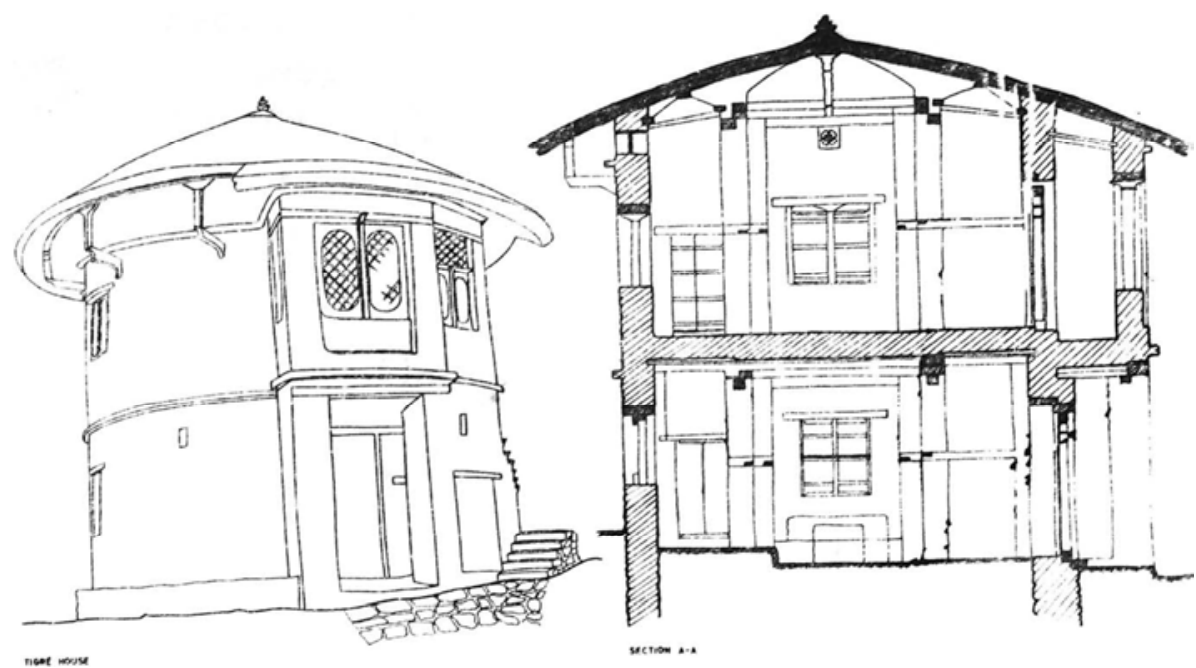

Figure 9. Sketch of $3 D$ and section of the building [17].
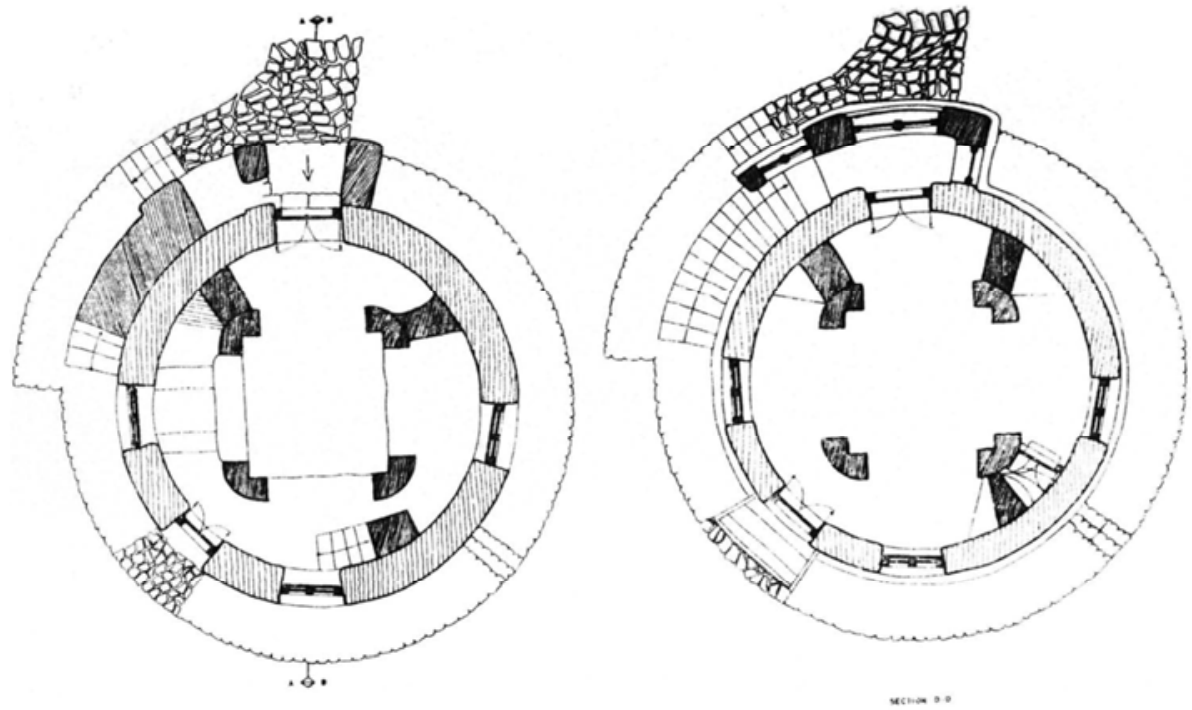

Figure 10. Ground and First floor plan of the building respectively [17]. 


\subsubsection{Structural Assessment of the Building}

The building is circular two story stone masonry building with a radius of $3 \mathrm{~m}$ internally and its wall height is $5 \mathrm{~m}$ with $60 \mathrm{~cm}$ thickness. Currently its roof is galvanized sheet cover but, previously it was thatched roof.

The floor is constructed by wooden and mud or earthen floor. Its ceiling is decorated by bamboo. The wall is constructed by thin and small stone and mud; internally it is plastered by mud.

The building has massive semicircular stone masonry external stair to upper floor. And its door and window are constructed and decorated by wooden materials.

In the middle of the wall, in the floor level, it has flat and thin stone called "Katsela" inserted to the wall to protect dampness. But, still it has cracks in the stone masonry wall and the wooden floor has deteriorated and decayed. It is in a bad condition

\subsubsection{Assessment of Conservation Practices of the Building}

Before 60 years the thatched roof removed and changed by galvanized sheet roof cover. In 2004 G.C the external wall has plastered partially by mud to protect from external wall crack. In 2009 G.C the vertically cracked part has plastered by cement in order to repair the cracked part.

\subsection{Case Study 3, Ato Weldegebriel Meshesha Building}

This historic building is two story or "Debri" rectangular building, located in Axum historic town which is northern parts of Tigrai region and its absolute locations of this building is $14^{\circ} 20.5^{\prime} 21^{\prime \prime} \mathrm{N}$ and $38^{\circ} 39^{\prime} 31.5^{\prime \prime} \mathrm{E}$. It also relatively located on "Hawelti" Kebele 08 and house no of 252 to the north west of Axum monuments approximately $350 \mathrm{~m}$ far from Axum tsion mariyam church to the North West direction.

Hadas Teklie, she is a house Sutter, is lives in the building at this time. According to Hadas the building aged to 115 years.

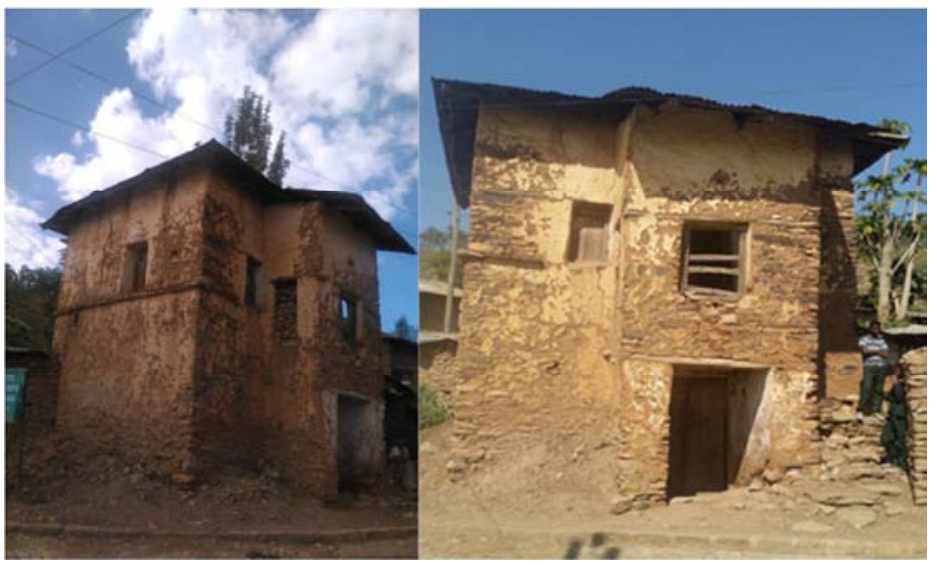

Figure 11. Ato Weldegebriel Meshesha building (by the author).

\subsubsection{Structural Assessment of the Building}

The building is rectangular two story or "Debri" stone masonry building with wall height of $6 \mathrm{~m}$ and $50 \mathrm{~cm}$ thickness. Currently its roof is galvanized sheet cover but, previously it was thatched roof.

The floor is constructed by wooden and mud or earthen floor. Its ceiling is decorated by bamboo and wooden elements. The wall is constructed by thin and small stone and mud; internally it is plastered by mud.
The building has massive L-shaped stone masonry external stair to upper floor. And its door and window are constructed and decorated by wooden materials.

In the middle of the wall, in the floor level, it has flat and thin stone called "Katsela" inserted to the wall to protect dampness. But, still it has cracks in the stone masonry wall and the wooden floor has deteriorated and decayed. It is in a bad condition.

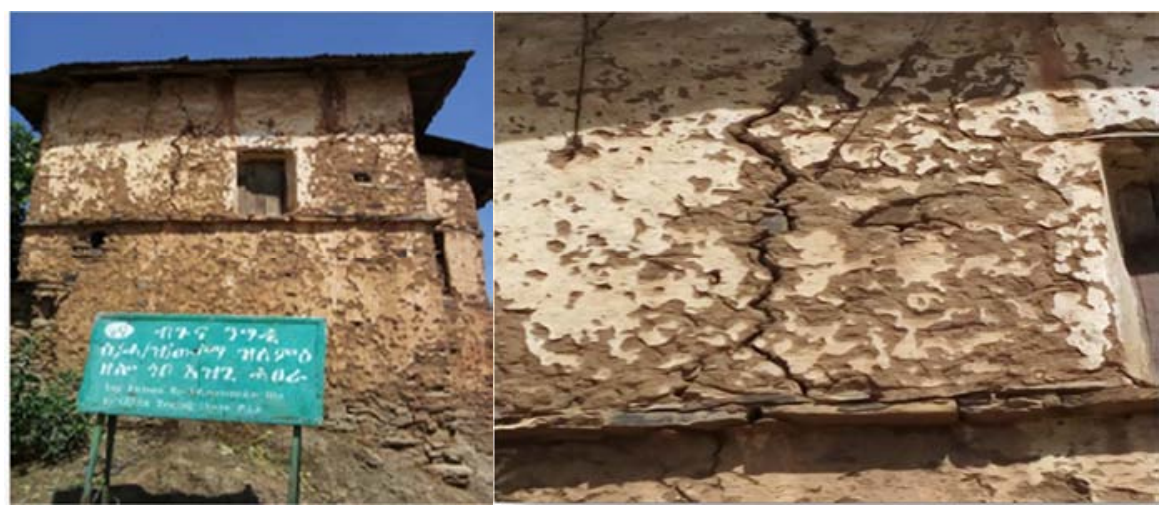

Figure 12. Vertical cracks of Ato Weldegebriel building (by the author). 


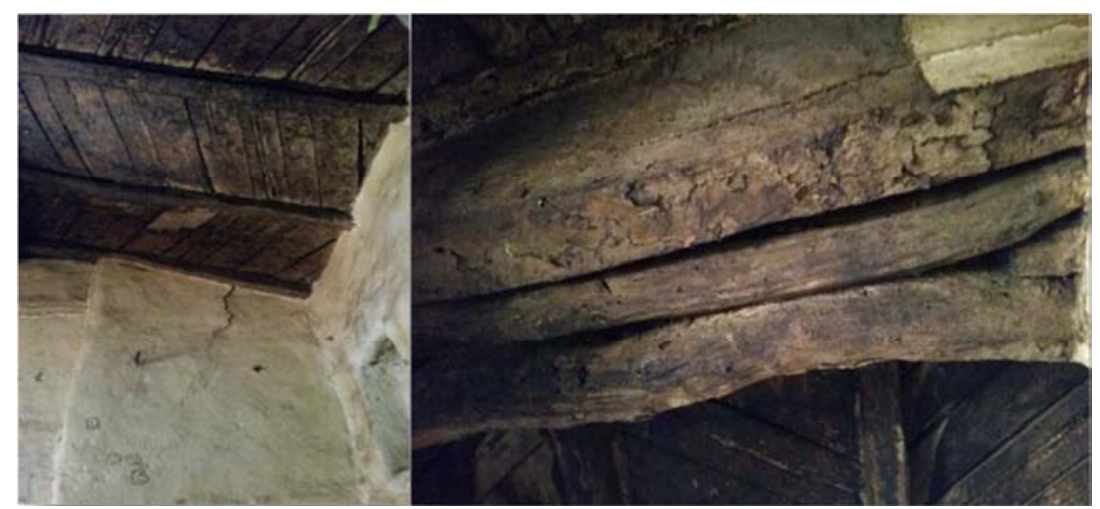

Figure 13. Cracked wall and the deteriorated wooden beam and ceiling.

\subsubsection{Assessment of Conservation Practices of the Building}

The first and the only practice of conservation in the building is mud plastering of the external wall and galvanized sheet cover of the roof from thatched roof, before 40 years to protect the external wall erosion.

\subsection{Case Study 4, Ato Yared Hailemariam Building}

This historic building is two story or "Debri" rectangular building, located in Axum historic town which is northern parts of Tigrai region and its absolute locations of this building is $14^{\circ} 21.5^{\prime} 34^{\prime \prime} \mathrm{N}$ and $38^{\circ} 43^{\prime} 34^{\prime \prime} \mathrm{E}$. It also relatively located on "Hawelti"/Kebele 08 and house no of 296 to the north of Axum monuments approximately $500 \mathrm{~m}$ far from Axum tsion mariyam church to the north direction.

Ato Hailemariam, the father of Ato Yared or the owner, is the grand child of the first residence or owner of the building. Ato Yared Hailemariam is living in the building at this time.
According to Ato Yared, the building aged to 140 years.

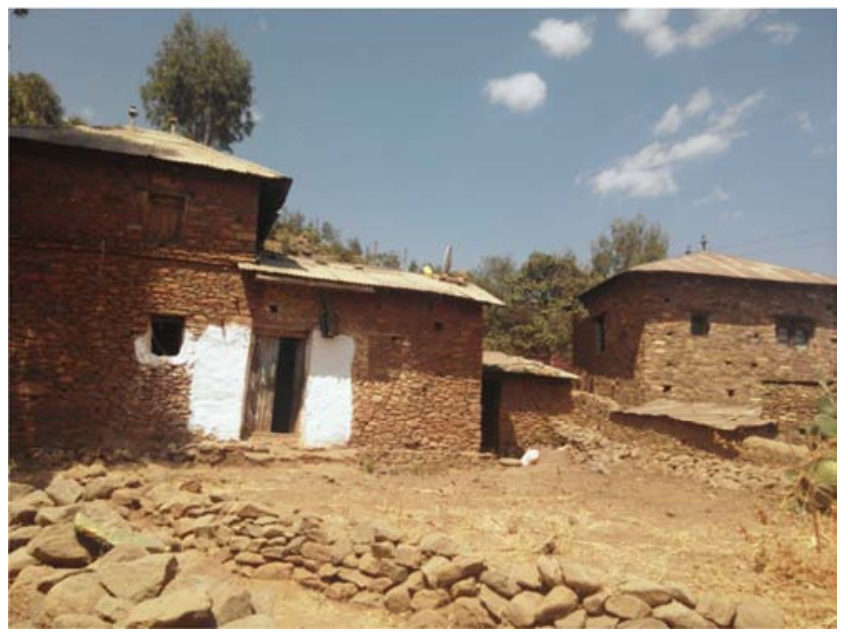

Figure 14. Ato Yared Hailemariam building (by the author)

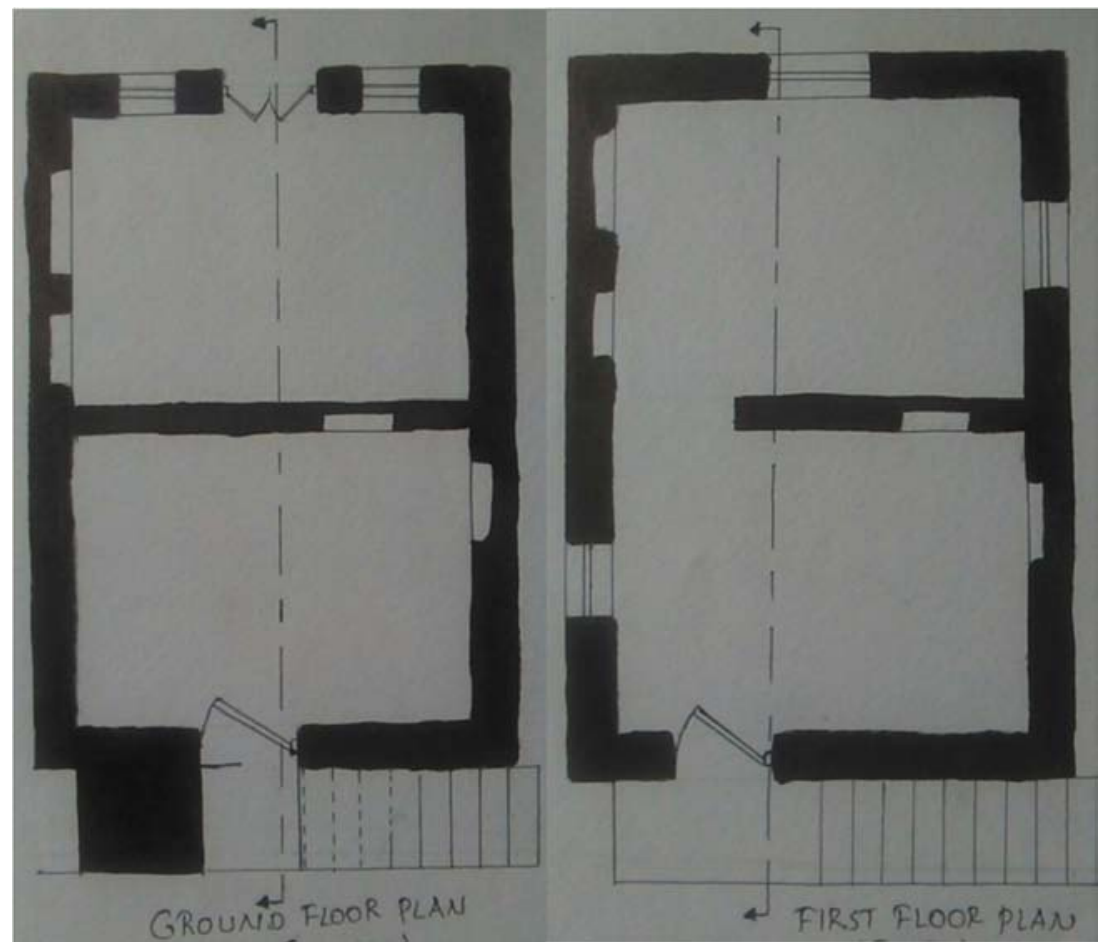




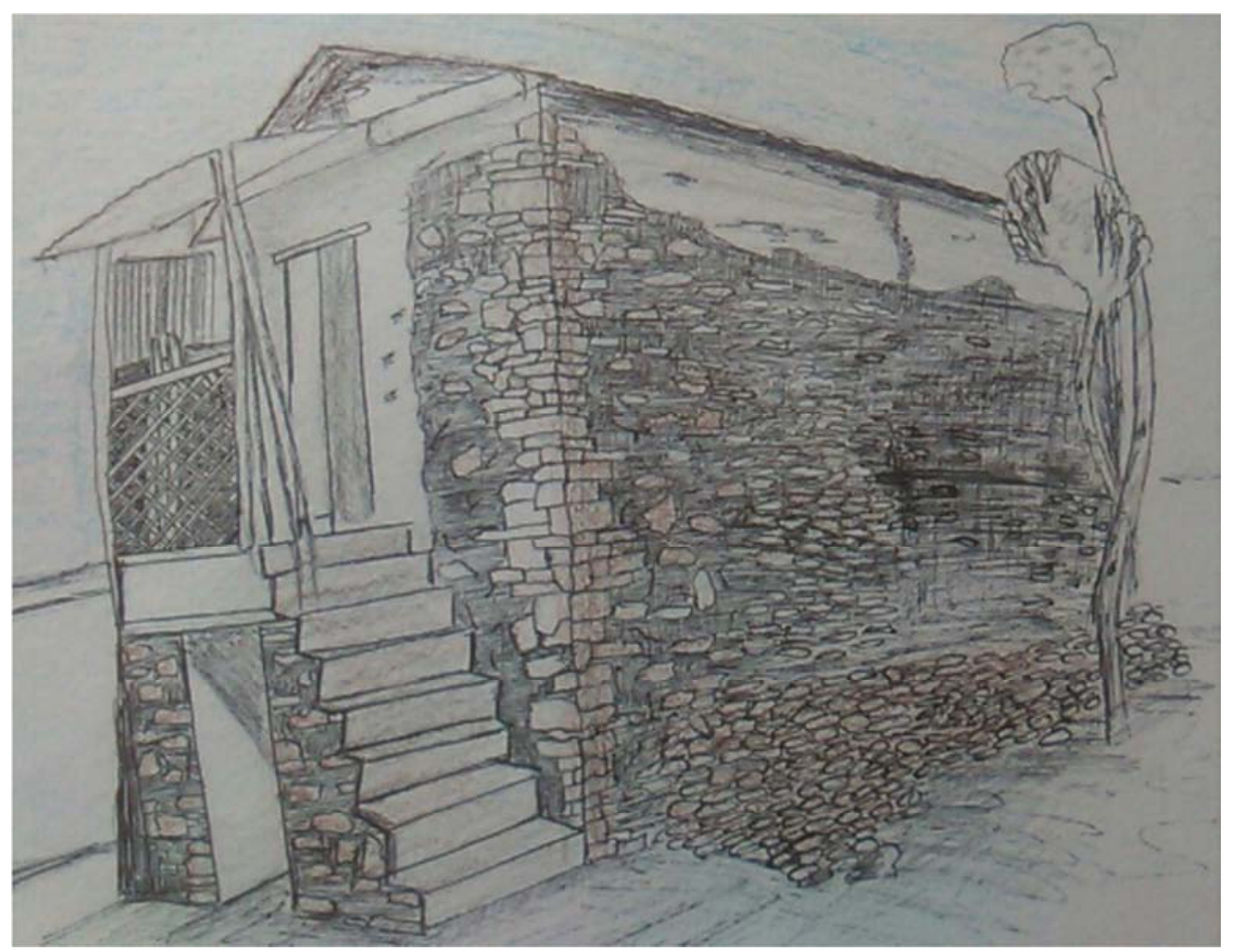

Figure 15. Plan of Ato Yared Hailemariam building (by the author).

\subsubsection{Structural Assessment of Ato Yared Hailemariom Building}

The building is rectangular two story or "Debri" stone masonry building with wall height of $6 \mathrm{~m}$ and $50 \mathrm{~cm}$ thickness. Currently its roof is galvanized sheet cover but, previously it was thatched roof.

The floor is constructed by wooden and mud or earthen floor. Its ceiling is decorated by bamboo and wooden elements. The wall is constructed by thin and small stone and mud; internally it is plastered by mud and lately by lime.

The building has massive one flight stone masonry external stair to upper floor. And its door and window are constructed and decorated by wooden materials.

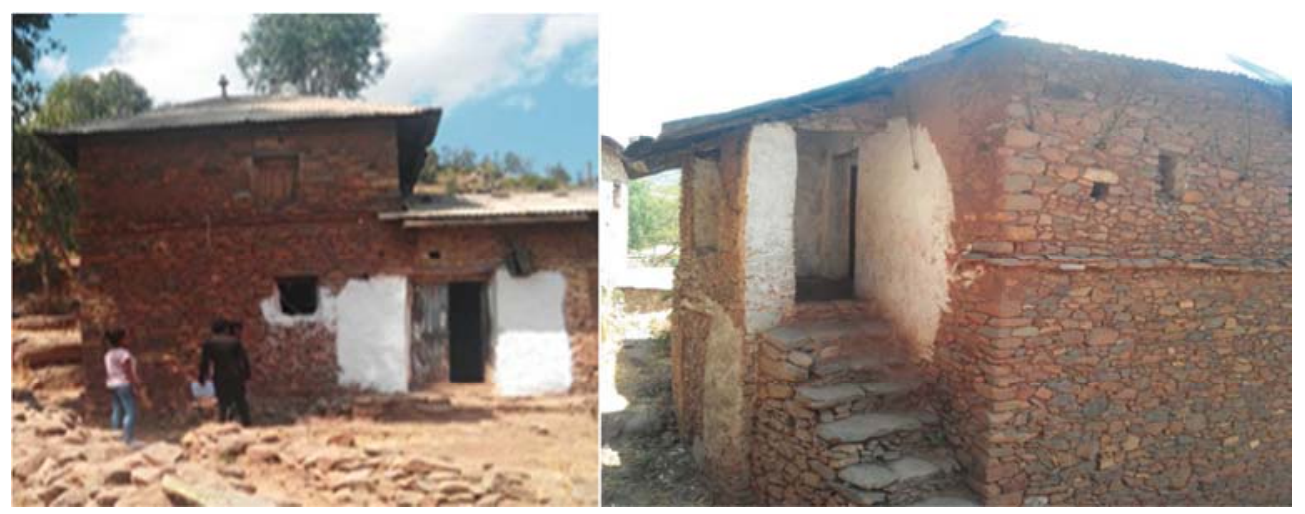

Figure 16. External view of the building; the stair, the door and window etc. (by the author).

\subsubsection{Assessment of Conservation Practices of the Building}

The first and the only practice of conservation in the building is lime plastering of the internal wall and galvanized sheet cover of the roof from thatched roof, before 40 years to protect the external wall erosion.

\subsection{Case Study 5, Basha Gebrehiwot Building}

This historic building is two story or "Debri" rectangular/square building, located in Axum historic town which is northern parts of Tigrai region and its absolute locations of this building is $14^{\circ} 22.5^{\prime} 34.6^{\prime \prime} \mathrm{N}$ and $38^{\circ} 44^{\prime} 35^{\prime \prime} \mathrm{E}$. It also relatively located on "Hawelti"/Kebele 08 and house no of 439 to the north of Axum monuments approximately $300 \mathrm{~m}$ far from Axum tsion mariyam church to the north direction.

W/ro Asemash Gebru, the grandchild of Basha Gebrehiwot, is living in the building at this time. According to $\mathrm{W} /$ ro Asemash Gebru, the building aged to 95 years. 


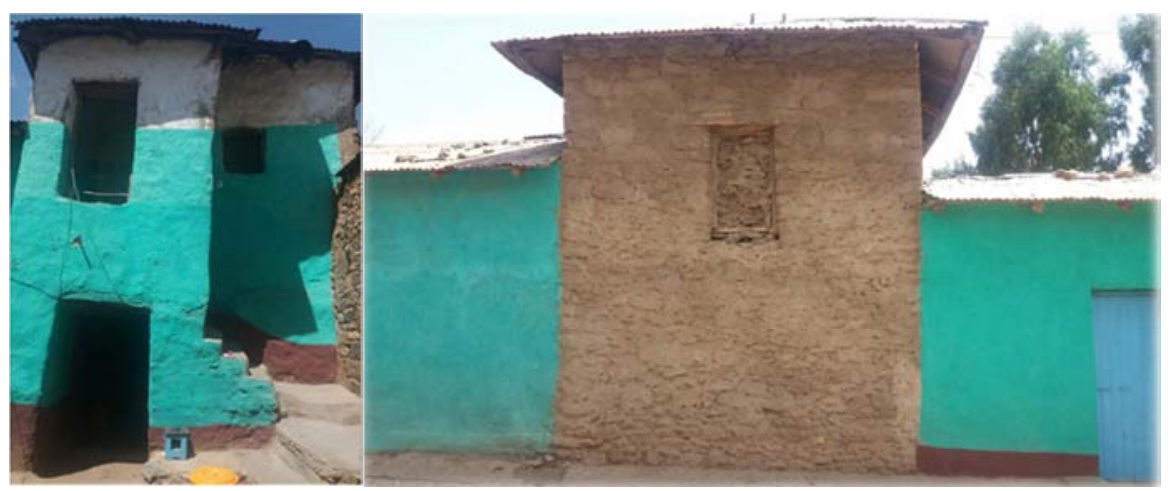

Figure 17. Front and rear view of Basha Gebrehiwot building (by the author).

\subsubsection{Structural Assessment of the Building}

The building is rectangular/square two story or "Debri" stone masonry building with wall height of $6 \mathrm{~m}$ and $50 \mathrm{~cm}$ thickness. Currently its roof is galvanized sheet cover but, previously it was thatched roof.

The floor is constructed by wooden and mud or earthen floor. Its ceiling is decorated by wooden elements. The wall is constructed by thin and small stone and mud; internally and externally in partial, it is plastered by mud and lately by lime and newly introduced chemical paint.

The building has small steps by stone masonry like external stair to upper floor. And its door and window are constructed and decorated by wooden materials. Some of the windows are closed by stone in the time of rooms' expansion and the street side windows. As shown in figure 17.

The wooden elements of earthen floor/slab have deteriorated and create floor height difference on ground floor. The wooden beam is supported by new pillars.
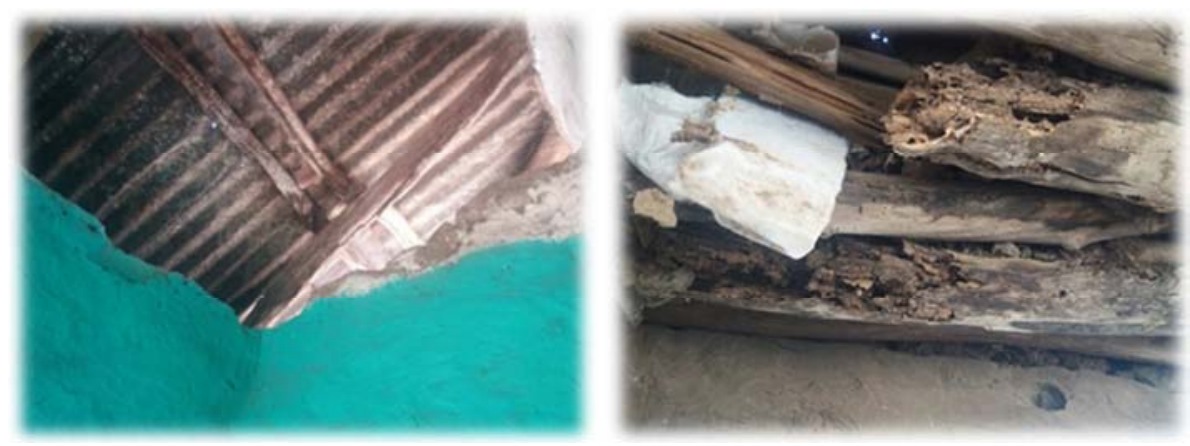

Figure 18. The deteriorated wooden beams and ceilings (by the author).

\subsubsection{Assessment of Conservation Practices of the Building}

The first practice of conservation in the building is lime plastering of the internal wall and galvanized sheet cover of the roof from thatched roof. Secondly, the external wall has plastered by cement before 23 years to protect the external wall erosion and finally the internal wall and some external part of the wall has painted by new chemical paint before 15 years.

\section{Analysis, Conclusion and Recommendation}

\subsection{Analysis}

From the above discussions the physical structure of the case studies are not in a good condition.

The roof; the roof of all case studies has changed from thatched roof to galvanized sheet cover and it is possible to compare with figure 19, view of Axum before 113 years. All roof covers was thatched roofs.
The wall; the stone masonry walls are partially cracked, some of them has plastered by cement and some of the deteriorated by rain erosion.

The floor and ceiling; the wooden elements of the flooring and ceiling are deteriorated by different reasons and some of the wooden beams are supported by additional pillars

Openings; the wooden doors and windows are deteriorated and partially changed to metal element.

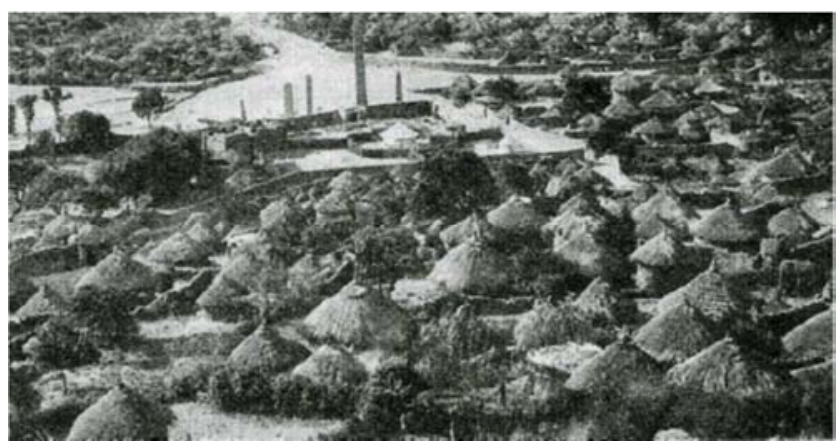

Figure 19. View of Axum on 1906 [18]. 


\subsection{Conclusion and Recommendation}

Since Axum is a world heritage site, every conservation activities and interventions of historical buildings should be based on the UNESCO/ICOMOS guide lines that is by conducting researches like condition assessments and others held by professionals. But, as the result and analysis shows all conservation and intervention activities are conducted by the residences and by the owners.

From the selected case studies, most of them their physical structure is not at a good condition because of ownership issues and improper conservation practices due to need of modernization and urbanization like cement plastering, chemical paint, electricity installation and others that affect its original fabric.

Responsible parties like governmental offices, universities, professional experts and stakeholders should document the vernacular houses and the conservation practices at different time and they should prepare conservation management plan or guidelines for the specific site to manage the conservation activities and practices. The responsible parties should work with the community in awareness creation to preserve those vernacular houses.

\section{References}

[1] P. Oliver, Dwellings; the vernacular houses world wide, London: phainor press, 2003.

[2] J. P. Bourdier, Dwellings, Settlements and Traditions: Crosscultural Perspectives., Boston: University Press of America., 1989.

[3] A. Rapoport, House Form and Culture., USA: Englewood cliffs, 1969.
[4] P. Oliver, Encyclopidia of Vernacular Architecture., London: portland, 1997.

[5] Silva, HE; Henriques FMA., Preventive conservation of historic buildings in temperate, climate., Attens: Energy build, 2015.

[6] Z. Geogres, Cultural heritage and economic theory., Norwich: University of East Anglia;, 2003.

[7] ARCCH, Standards and Guidelines for the Conservation of Historic Places in Canada, Canada: ARCCH, 2004.

[8] Y. F. Tuna, Space and place: the perspective of experience., London: Edward Arnold Ltd, 1977.

[9] p. Hubbard and K. R., Key thinkers on space and place., London: SAGE, 2010.

[10] Kuyan, Conservation of heritage buildings: maintaining old government buildings in Kuala Lumpur after gazetted period., Kuala: university of Malaya, 2003.

[11] CSA, central statistics of Ethiopia, Addis Ababa: CSA, 2008.

[12] D. W. Phillipson, Archaeology at Aksum, Ethiopia 1993-7, Nairobi: British Institute in eastern Africa, 2000.

[13] ICOMOS, "Conservation Evaluation Report of the World Heritage Site of Aksum," ICOMOS, USA, 2012.

[14] UNESCO/ICOMOS, "High Level Reactive Monitoring Mission to Aksum," ICOMOS, USA, 2013.

[15] U. ICOMOS, "Conservation Evaluation Report of the World Heritage Site of Aksum," ICOMOS, USA, 2012.

[16] D. Phillipson, Foundations of an African Civilization. Aksum and the Northern Horn., Suffolk: James Currey, 2012.

[17] G. Naizgi, some traditional housing types of Ethiopi, Britain: Barrie and Jenkins ltd, 1971.

[18] E. Littman, Deutsche Aksum Expedition, Berlin: Reimer, 1913. 